\title{
The role of protein kinase $C$ in the desensitization of rat pancreatic islets to cholinergic stimulation
}

\section{E J Verspohl and A Wienecke}

University of Münster, Institute of Pharmaceutical Sciences, Department of Pharmacology, Hittorfstr. 58-62, 48149 Münster, Germany

(Requests for offprints should be addressed to E J Verspohl, Department of Pharmacology, Institute of Pharmaceutical Sciences, Hittorfstr. 58-62, 48149 Münster, Germany)

\begin{abstract}
It is well known that protein kinase $\mathrm{C}$ (PKC) plays an important role in mediating insulin secretion in response to cholinergic stimulation. In various cells $\mathrm{PKC}$ also mediates a desensitization process. The role of PKC for homologous desensitization of the insulin response to repetitive stimulation with the muscarinic agonist carbachol (CCh) was investigated in perifusion experiments using isolated rat pancreatic islets. Repetitive (six times) stimulation with CCh $(100 \mu \mathrm{M})$ reduced insulin secretion over time (up to $50 \%$ during the second challenge). This was not a toxic effect since the desensitizing effect was mostly washed out after $45 \mathrm{~min}$. When PKC was downregulated by long term preincubation $(20 \mathrm{~h})$ with $200 \mathrm{nM}$ phorbol $12-$ myristate 13-acetate (TPA), the initial stimulation of insulin release by CCh was reduced by $50 \%$, and a desensitization by further CCh stimulation was no longer obvious. In contrast, when other compounds with different mechanisms of actions for inactivating PKC were used, i.e. PKC inhibitors such as staurosporin $(100 \mathrm{nM})$, Ro 31-8220 $(5 \mu \mathrm{M})$ or PKC peptide(19-31), the insulin secretion in response to $\mathrm{CCh}$ was reduced but the desensitization was not abolished. When PKC was down-
\end{abstract}

regulated or inhibited by the above methods, the PKC activator phorbol 12-myristate 13-acetate (TPA; $200 \mathrm{nM}$ ) was no longer able to evoke an increase in insulin secretion during static incubation, i.e. these control experiments indicate a real PKC inhibition. When heparin $(50 \mu \mathrm{g} / \mathrm{ml})$, an inhibitor of G-protein coupled receptor kinase (GRK), was used, the desensitization of the cholinergic stimulation of insulin release remained unchanged. The data indicate that PKC plays a role in CCh-mediated insulin secretion and also show a desensitization of this effect after repetitive stimulation with CCh. The data further indicate that specific PKC isoenzymes that are inhibited by staurosporin or Ro 31-8220 do not take part in the desensitization process, while isoenzymes that are downregulated by TPA are involved. It may be speculated that a hitherto unknown PKC isoenzyme that is downregulated by TPA but not by the other used PKC inhibitors is involved in the desensitization process, or that a nonspecific effect of TPA is involved. Members of the GRK family are not involved in the desensitization process of CCh.

Journal of Endocrinology (1998) 159, 287-295

\section{Introduction}

Protein kinase C (PKC) belongs to the serine/threonine phosphorylating kinases. It is a family of at least 12 isoenzymes that interact intracellularly by phosphorylating specific target proteins. PKC is involved in signal transduction, cellular processes such as secretion (e.g. insulin secretion), in desensitization, in gene expression and cell differentiation.

In general, desensitization can be achieved at the receptor level, by a decrease of receptor coupling factors such as G-proteins, a decrease in second messengers (e.g. downstream phospholipase C (PLC), by the reduced efficiency of second messengers, e.g. less mobilization by inositol 1,4,5-triphosphate $\left(\mathrm{IP}_{3}\right)$ of $\mathrm{Ca}^{2+}$ from an intracellular pool (McArdle et al. 1996) or acceleration of $\mathrm{IP}_{3}$ receptor degradation (Wojcikiewicz et al. 1994). PKC is involved in the homologous desensitization of $\delta$-opioid receptors (Ueda et al. 1995) but not bombesin receptors (Frankel \& Viallet 1993), histamine- and ATP receptormediated effects (Lin \& Chuang 1993, Dickenson \& Hill 1993). With respect to other receptors, e.g. angiotensin II receptors, inhibition of $\mathrm{PKC}$ resulted in desensitization distal from the receptor itself (Tang et al. 1995). The atrial natriuretic peptide (ANP) receptor is desensitized in a PKC-dependent and -independent way (Potter \& Garbers 1994).

In general there appears no specific rule regarding the involvement of PKC. PKC is involved in the heterologous desensitization of carbachol (CCh) binding sites mediated by cholecystokinin (Doi et al. 1993). The underlying mechanism of a homologous muscarinic receptor desensitization is a change in CCh receptor affinity and its regulation by G-proteins (Hishinuma et al. 1993). It is 
already known that chronic exposure of islets to the muscarinic agonist $\mathrm{CCh}$ suppresses insulin release to a subsequent glucose plus CCh challenge (Zawalich \& Kelley 1995). However the mechanism has not been investigated further.

Several PKC isoenzymes are present in $\beta$-cells: $\alpha, \beta, \delta$, $\varepsilon, \zeta$ and 1 . Involvement of PKC isoenzymes is shown in a number of ways. PKC inhibitors can be divided into three groups: inhibitors such as the indolecarbazoles (staurosporin) and bisindolylmaleinimide (Ro 31-8220) interact with the catalytic domain (Tamaoki et al. 1986); PKC peptide(19-31) with a pseudosubstrate sequence (same sequence as the pseudosubstrate region of $\mathrm{PKC} \alpha$ ) interacts with the PKC substrate binding site. In contrast to staurosporin and Ro 31-8220 which act on the C3 region of the catalytic domain of PKC close to the ATP binding site, the PKC pseudopeptide(19-31) binds to the C4 region of the catalytic domain. The phorbol ester (phorbol 12-myristate 13-acetate (TPA)) (Lee \& Bell 1986) interacts with the regulatory domain of PKC. Long term activation of PKC by TPA leads to a proteolytic degradation and hence inactivation of PKC.

Different compounds have been used in our experiments since no specific PKC inhibitor is known. Using a number of approaches we investigated whether PKC is involved in homologous desensitization of rat pancreatic islets to CCh.

\section{Materials and Methods}

Animals

Adult Wistar rats of either sex weighing between 230 and $330 \mathrm{~g}$ were used. They were given a standard pellet diet (Altromin, Lage, Germany) and tap water and allowed to feed ad libitum. Animals were kept at $22{ }^{\circ} \mathrm{C}$ with a ratio of $12 \mathrm{~h}$ light:12 h darkness.

\section{Chemicals}

The following were purchased: soybean trypsin inhibitor (SBTI), bacitracin and Hepes (2-(4-(2-hydroxyethyl)-1piperazinyl)-ethanesulfonic acid) from Sigma Chemical Co. (St Louis, MO, USA); $\alpha$-D-glucose was obtained from Serva Feinbiochemica (Heidelberg, Germany); bovine serum albumin (BSA) fraction $\mathrm{V}$ from Behringwerke AG (Marburg, Germany); and collagenase (CLS grade, 126-196 U/ml) from Worthington Biochemicals Corp. (Freehold, NJ, USA). Insulin was determined radioimmunologically using anti-insulin antibodies from Linco Research (St Louis, MO, USA), ${ }^{125}$ I-insulin was a gift from Behringwerke AG and rat insulin (as a standard) was from Novo Research Institute (Copenhagen, Denmark). CCh, TPA, staurosporin and heparin were from Sigma (Deisenhofen, Germany); PKC peptide(19-31) was from Boehringer Mannheim (Mannheim, Germany) and Ro
31-8220 from Roche (Welwyn Garden City, Herts, UK). All other chemicals and reagents were of analytical grade supplied by E Merck (Darmstadt, Germany).

\section{Isolation of rat pancreatic islets}

Isolation of pancreatic islets was as described by Kuo et al. (1973) with slight modifications (Verspohl \& Ammon 1980). Pancreata were isolated from the ether-anesthetized rat, minced, and washed twice with $20 \mathrm{ml}$ ice-cold Krebs-Ringer buffer plus $10 \mathrm{mM}$ Hepes (Krebs-RingerHepes (KRH) buffer) containing $2 \cdot 8 \mathrm{mM}$ glucose, $1 \mathrm{mg} /$ $\mathrm{ml}$ bacitracin, $0.2 \mathrm{mg} / \mathrm{ml}$ SBTI, and $0.02 \%$ albumin. Pancreas pieces were soaked and then shaken in a $37^{\circ} \mathrm{C}$ water bath in the presence of $650 \mathrm{U}$ collagenase/g tissue suspension. After 15-18 min of incubation the tissue suspension was transferred into $10 \mathrm{ml}$ ice-cold Hanks' solution. Islets were separated by sedimentation and collected as described elsewhere (Kuo et al. 1973).

\section{Incubation conditions and determination of insulin}

To measure hormone secretion in static batch incubations, five islets were incubated for $90 \mathrm{~min}$ at $37^{\circ} \mathrm{C}$ in $1 \mathrm{ml}$ KRH buffer, $\mathrm{pH} 7 \cdot 35$, containing $5 \mathrm{mg} / \mathrm{ml}$ bovine albu$\mathrm{min}, 1 \mathrm{mg} / \mathrm{ml}$ bacitracin and $0 \cdot 2 \mathrm{mg} / \mathrm{ml} \mathrm{SBTI}$ and other additions as shown in the figure legends. CCh was used in the presence of $3.0 \mathrm{mM}$ glucose, a substimulatory concentration, since it is an initiator of insulin release. Hormones released into the medium by islets were assayed by radioimmunoassay using rat insulin as a standard.

\section{Perifusion studies}

Fifty freshly isolated islets were used for each experiment. The perfusion medium was a KRH buffer supplemented with $0 \cdot 25 \%$ BSA. The basal medium contained $8.3 \mathrm{mmol} / 1$ glucose and the test medium additional compounds as indicated in the legends to the figures. The medium reservoirs were maintained at $37^{\circ} \mathrm{C}$. During the first $15 \mathrm{~min}$ after the isolation procedure the perifusion flow rate was adjusted to $1.2 \mathrm{ml} / \mathrm{min}$. In the next $15 \mathrm{~min}$ the islets were allowed to equilibrate under constant perfusion flow rate and insulin release was not determined. In the following $12 \mathrm{~min}$ four samples were collected to determine the basal insulin secretion. A CCh challenge was then given for $6 \mathrm{~min}$ by switching to the test medium. Data are shown in absolute terms (insulin concentration) and also as integrated amounts of released insulin over time (6-min area under curve (AUC)).

\section{Electropermeabilization (electroporation)}

Since compounds such as PKC peptide(19-31) and heparin are not cell permeable, islets had to be permeabilized. 
Experiments describing this procedure have been recently published (Verspohl et al. 1997). For some experiments islets were electrically permeabilized in a permeabilization buffer containing $70 \mathrm{mM}$ 2-hydroxyethanesulfonic acid, $70 \mathrm{mM}$ potassium chloride, $10 \mathrm{mM}$ Hepes, $1 \mathrm{mM} \mathrm{MgCl}$, $1 \mathrm{mM}$ ATP, $3 \mathrm{mM}$ glucose, $1 \mathrm{mM}$ EGTA and $0.5 \mathrm{mg} / \mathrm{ml}$ BSA. The $\mathrm{Ca}^{2+}$ concentration $\left(5 \times 10^{-8} \mathrm{M}\right)$ was calculated according to the method described by Fabiato \& Fabiato (1979). Islets were permeabilized by five exposures (15-s intervals, $\tau 200 \mu \mathrm{s})$ to an electric field of $1 \cdot 36 \mathrm{kV} / 0 \cdot 4 \mathrm{~cm}$. As shown recently using the same electropermeabilization protocol, all of the cells within the islet appear to be permeabilized to a similar extent (Jones et al. 1992). We obtained similar results when the fluorescence of cells was visualized both spectrophotometrically and microscopically for uptake of cell membrane impermeable propidium iodide, fluorescein isothiocyanate (FITC)labeled antibodies and FITC-labeled dextran (Verspohl et al. 1997). Using propidium iodide as a marker of cell viability and effectiveness of electropermeabilization, an effectiveness of electroporation of $81.5 \%$ was found, and a cell viability of $64 \%$ of all cells either electroporated or not was shown. This confirms the data of Yaseen et al. (1982). The cells appear to reseal since control experiments indicated a rapid outflow of lactate dehydrogenase for the first 15-20 min which levels off thereafter and is no longer observed after $45 \mathrm{~min}$ (Verspohl et al. 1997). Since the molecular weight of lactate dehydrogenase $(140000)$ is in the range of that of immunoglobulins it is possible that immunoglobulins significantly cross the membrane due to the permeabilization procedure (see Verspohl et al. (1997)).

In order to block the effects of PKC by intracellularly presenting PKC peptide(19-31), 50 islets were incubated in $400 \mu \mathrm{l}$ permeabilization buffer containing the compound. After electroporation islets were kept untreated at $22{ }^{\circ} \mathrm{C}$ for $60 \mathrm{~min}$ to seal the pores. Then the 50 islets were either perifused for different periods or five islets were batch incubated each in the presence of either stimulator for $90 \mathrm{~min}$ at $37^{\circ} \mathrm{C}$ as mentioned above using $\mathrm{KRH}$ buffer, pH $7 \cdot 35$, containing $5 \mathrm{mg} / \mathrm{ml}$ bovine albumin, $1 \mathrm{mg} / \mathrm{ml}$ bacitracin, and $0.1 \mathrm{mg} / \mathrm{ml} \mathrm{SBTI}$. The incubation conditions and medium composition were the same whether the islet had been electroporated before or not.

\section{Insulin assay}

Insulin concentrations in the effluent and the reservoir, or as released during static incubation, were measured in duplicate by a double-antibody method using specific antibodies and rat insulin as a standard.

\section{Compounds used and their incubation conditions (a critical reflection)}

To address the problem of desensitization we used PKC inhibitors which differed in their mechanism of action on the enzyme: TPA on a long run inactivates the enzyme by proteolysis; staurosporin and Ro 31-8220 interact with the catalytic domain of PKC, and PKC peptide(19-31) has a pseudosubstrate sequence which interacts with the substrate binding site of PKC. The outcome depends on the concentration of inhibitor used. Reports differ with respect to the concentration and/or time used of the various $\mathrm{PKC}$ inhibitors, e.g. the $\mathrm{IC}_{50}$ for staurosporin with respect to the isoform PKC $\delta$ is 100 -fold different depending on the substrate used (McGlynn et al. 1992, Mizuno et al. 1993, Birchall et al. 1994).

The optimum time and concentration were checked for rat pancreatic islets by static incubation to be sure that under the conditions used in our study, PKC was inhibited (Fig. 1), i.e. there was no acute TPA stimulatory effect on insulin release. A total of $200 \mathrm{nM}$ TPA acutely increased insulin release. A 20-h preincubation with $200 \mathrm{nM}$ TPA as well as 15 -min preincubation with either $100 \mathrm{nM}$ staurosporin, 5 or $10 \mu \mathrm{M}$ but not $2 \mu \mathrm{M}$ Ro 31-8220, or addition of approximately $10 \mu \mathrm{M}$ PKC peptide(19-31) into electroporated islets, led to an inhibition of the effect of TPA on insulin release (Fig. 1) indicating the effectiveness of treating the cells with either compound leading to inactivation of PKC. Other concentrations were also tried (data not shown).

The optimum concentration of the compounds was: 200 $\mathrm{nM}$ for TPA, $100 \mathrm{nM}$ for staurosporin and $5-10 \mu \mathrm{M}$ for Ro 31-8220. The exact intracellular concentration of the PKC peptide(19-31) after electroporation could not be determined; the extracellular concentration during the electroporation process was $10 \mu \mathrm{M}$.

\section{Statistics}

For statistical evaluation multiple comparisons of means were carried out by one-way analysis of variance followed by a post-hoc test (Newmans-Keul test).

\section{Results}

In Fig. 2 (upper panel) a homologous desensitization of the $\mathrm{CCh}$ effect is shown for perifused rat pancreatic islets. When the islets were challenged six times there was a decrease in the CCh effect on insulin release over time. When challenges were interrupted for $45 \mathrm{~min}$, there was a recovery of the stimulatory effects of CCh in the seventh challenge.

In addition to a 'true' desensitization (alteration in stimulus-secretion coupling) there is a depletion of intracellular insulin stores ('exhaustion') typical for a perifusion system as a consequence of chronic stimulation. Due to this 'run down' of the system data are also expressed as $\%$ AUC (integrated amounts of insulin secretion over time) to compensate for this effect (Fig. 2, middle panel). As a control, the \% increase in AUC is also shown for 

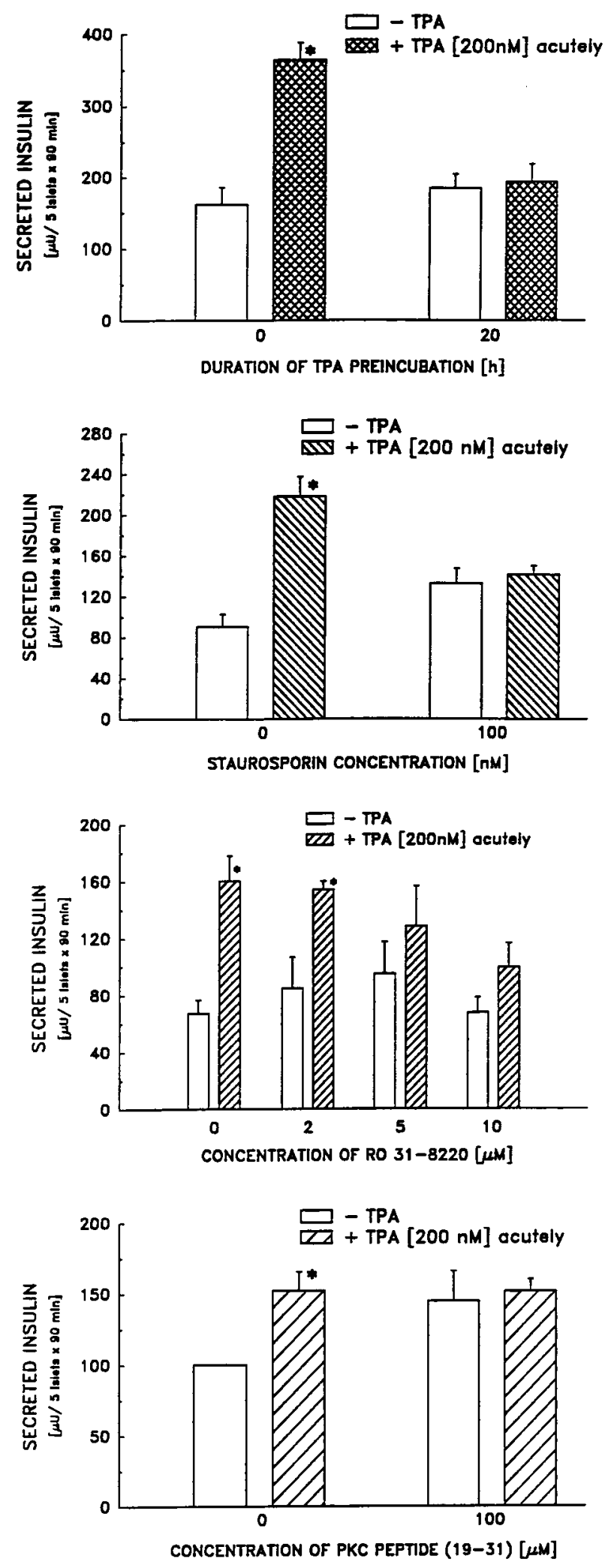

stimulation by $8.3 \mathrm{mM}$ glucose (Fig. 2, lower panel); in contrast to $\mathrm{CCh}$, glucose does not show a desensitizing effect.

The effect of 20-h TPA pretreatment was also investigated. Figure 3 shows a significant decrease in the stimulatory effect of $\mathrm{CCh}$ (first challenge). A further decrease of insulin release (desensitization) was not observed during another five CCh challenges.

When, however, PKC was inhibited by other methods, i.e. using $100 \mathrm{nM}$ staurosporin, $5 \mu \mathrm{M}$ Ro 31-8220 and $10 \mu \mathrm{M}$ PKC peptide(19-31), there was an inhibition of insulin release at the first CCh challenge (Fig. 4). The homologous desensitization to the CCh effect was not interrupted by either compound.

The effect of $50 \mu \mathrm{g} / \mathrm{ml}$ heparin on the CCh-mediated desensitization was also investigated; heparin is known to inhibit G-protein coupled receptor kinase (GRK) (Benovic \& Gomez 1993). The CCh-induced desensitization action of the system was not affected by the addition of $50 \mu \mathrm{g} / \mathrm{ml}$ heparin in the extracellular medium during electroporation of the islets (when the first challenge was normalized to $100 \%$ because of the electroporation procedure, the second challenge tended to be lower: $43 \pm 30-19 \pm 11$; the third challenge $46 \pm 15-21 \pm 7$; fourth challenge $18 \pm 9-21 \pm 8 \%$; all data were not significantly different from their individual control, i.e. no desensitization was obvious).

\section{Discussion}

$P K C$ involvement in CCh-induced insulin release

$\mathrm{CCh}$ is known to potentiate the glucose $(8.3 \mathrm{mM})$ mediated insulin release and specific $M_{3}$ receptors have been demonstrated in rat pancreatic islets (Verspohl et al. 1990). PKC is involved in the stimulatory effect of CCh (Persaud et al. 1989, Wollheim \& Regazzi 1990) which is confirmed by our data using TPA. This inhibitory effect was weaker with respect to PKC peptide(19-31) and staurosporin; since staurosporin is known to inhibit tyrosine kinases as well (Guma et al. 1992) this non-selectivity may result in a counter regulatory increase as it was recently shown for tyrosine kinase inhibitors (Verspohl et al. 1995). In islets acetylcholine-induced $\mathrm{IP}_{3}$ levels are also influenced by TPA pretreatment (Gao et al. 1994) and an acute addition of TPA decreases CCh-induced increases in $\mathrm{Ca}^{2+}$ concentration and production of $\mathrm{IP}_{3}$ (Arkhammar et al. 1994).

Figure 1 Effect of a long term (20 h) TPA (200 nM) preincubation and preincubation (15 $\mathrm{min}$ ) with various concentrations of staurosporin, Ro 31-8220 and PKC peptide(19-31) on the insulinotropic effect of $200 \mathrm{nM}$ TPA (static experiments). Five rat pancreatic islets were incubated with $8.3 \mathrm{mM}$ glucose plus $200 \mathrm{nM}$ TPA acutely for 90 min after pretreatment with the indicated compounds. Data are expressed as means \pm S.E.M. of 3-12 experiments; ${ }^{*} P<0.05$ vs absence of TPA (acutely). 

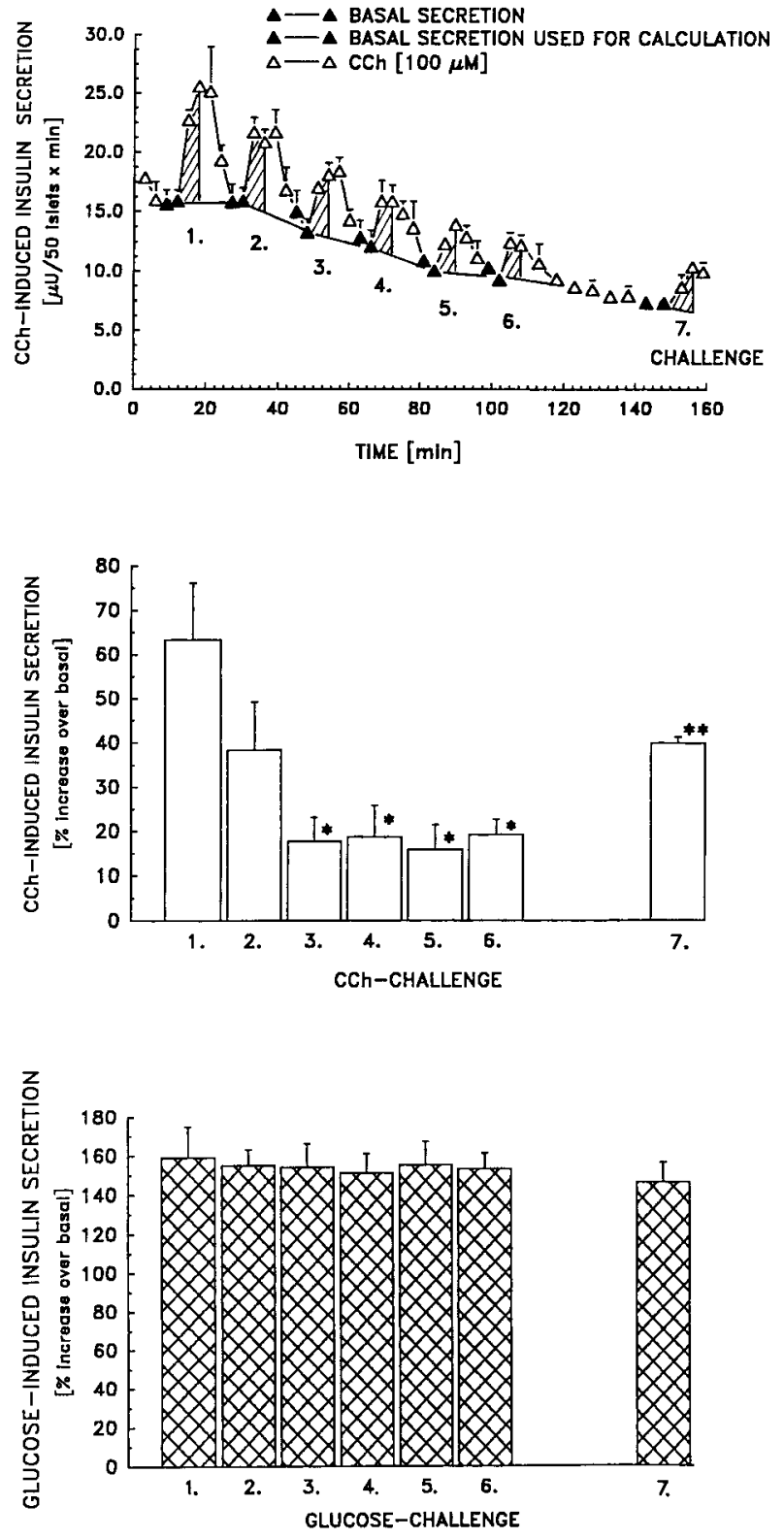

Figure 2 Desensitization of CCh-induced insulin release after repetitive $\mathrm{CCh}$ addition (perifusion experiment). Fifty rat pancreatic islets were perifused at a glucose concentration of $8.3 \mathrm{mM}$. They were challenged seven times as indicated. Basal secretion is calculated from the last $3 \mathrm{~min}$ prior to the next CCh challenge. The top panel shows the absolute released amounts of insulin for every 3 min ( 6 min=challenge time indicated by the hatched area). Since the insulin baseline shows a run down (upper panel), the data are recalculated: the stimulatory effect is also shown as a percentage increase over basal at the individual challenge time point, AUC (integrated area under the curve) (middle panel). In control experiments islets were challenged seven times by switching from 3.0 to $8.3 \mathrm{mM}$ glucose (lower panel). Data are expressed as means \pm S.E.M. of 3-7 experiments; One-way ANOVA was performed: $P<0.01 ;{ }^{*} P<0.05$ vs first stimulation; ${ }^{* *} P<0.05$ vs sixth stimulation.
Homologous desensitization of the CCh-modulated insulin release

Desensitization includes the decrease in the biologic response to a specific agent and the restoration of the effect after regenerating the system. The CCh effect desensitizes very quickly, already after the first challenge. The CCh effect was restored indicating that no simple toxic effect mimicked desensitization. This was carefully controlled by using $8.3 \mathrm{mM}$ glucose since a run down typical for a perifusion system might have obscured the interpretation of our data.

\section{PKC involvement in desensitization}

Some data hint to the possibility that the activation of PKC by CCh leads to a desensitization: 20-h TPA pretreatment which degrades PKC leads to an inhibition of the desensitization process in islets. This has already been shown for $\mathrm{M}_{3}$ receptors in other cell systems (Yamatani et al. 1988, Maruyama 1989, Tan \& Marty 1991, reviewed by Berrie \& Elliott 1994). However, the observation that desensitization of PLC-coupled muscarinic receptors is mediated by PKC (Haga et al. 1990) is not supported by all studies as described by Benya et al. (1995).

In contrast to TPA, all other compounds used to inhibit PKC such as staurosporin, Ro 31-8220 and PKC peptide(19-31) were not able to abolish inhibition of CCh-induced desensitization. With respect to staurosporin this is surprising since this compound is able to do so with other PLC-coupled receptor systems such as cholecystokinin (Willems et al. 1993), or with muscarinic receptors in other systems such as the lacrimal gland (Tan \& Marty 1991). However, staurosporin did not desensitize those receptors which are not linked to PLC, e.g. histamine-1 receptors (Zamani et al. 1995). Concerning Ro 31-8220 our data are in line with those for $M_{3}$ receptors in other cell lines (Tobin et al. 1993) and reflect what is known for other receptors coupled to PLC (Barr \& Watson 1994, Lattion et al. 1994). With respect to other receptors other groups also showed a difference when either TPA or staurosporin for PKC downregulation were used in rat pancreatic islets, i.e. the cholecystokinininduced insulin release is inhibited by long term pretreatment with TPA but not with staurosporin (Karlsson \& Ahrén 1991).

\section{Selectivity of PKC inhibitors (a critical reflection)}

Maximum selectivity of some compounds used was not achieved, e.g. staurosporin inhibits other protein kinases. The lack of selectivity is due to the huge homologies in the catalytic domain of many kinases (Bruns et al. 1991). Staurosporin is the most potent inhibitor $\left(K_{\mathrm{i}}=\sim 2 \mathrm{nM}\right)$ (Kase et al. 1987); however using a 10-fold higher concentration leads to inhibition of PKA, of CaMKII (calciumcalmodulin dependent kinase II) and of phosphorylase 


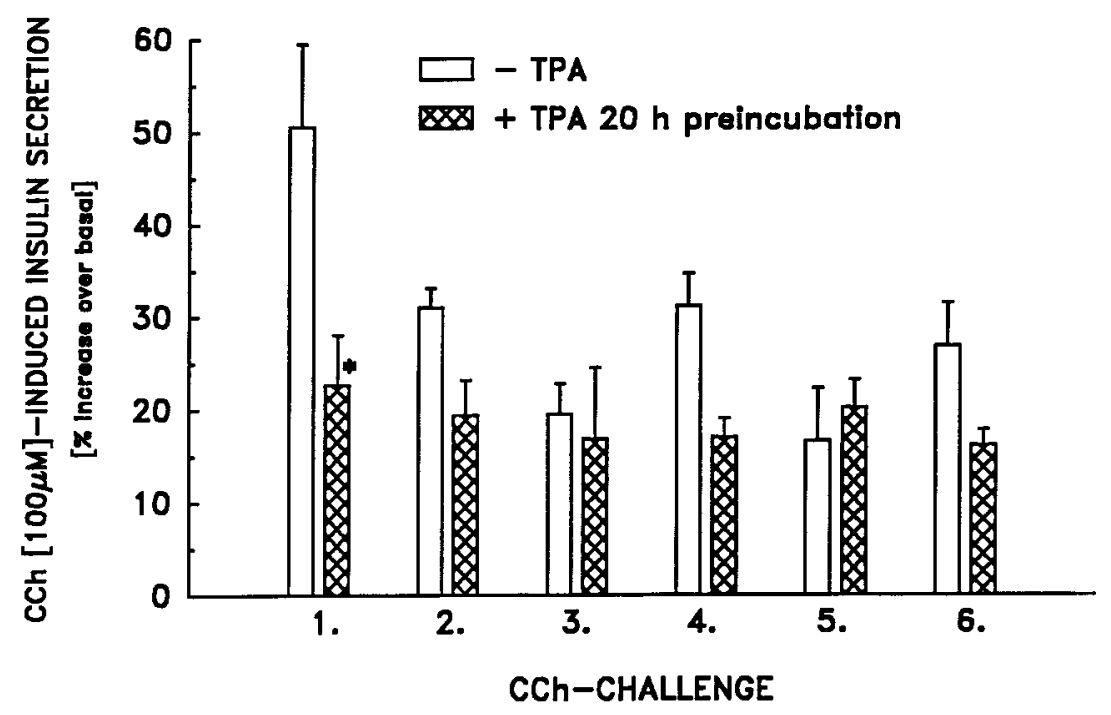

Figure 3 Effect of long term TPA preincubation on CCh effects on insulin release, especially with respect to desensitization. After 20-h preincubation with or without $200 \mathrm{nM}$ TPA, 50 rat pancreatic islets were perifused at a glucose concentration of $8.3 \mathrm{mM}$. The percentage increase of insulin secretion over basal (last 3 min prior to challenge) is shown for six CCh challenges. Data are expressed as means \pm S.E.M. of 5-8 experiments; one-way ANOVA $P<0.001$ for desensitization in the absence of TPA-preincubation; $P=0.9$ (not significant (NS)) for desensitization after 20-h TPA pretreatment; * $P<0.05$ insulin release with or without TPA pretreatment.

kinase (Nixon et al. 1992). A total of $1000 \mathrm{nM}$ staurosporin leads to $90 \%$ inhibition of insulin receptor tyrosine kinase (Guma et al. 1992) which is involved in the feedback of insulin release on its release (Verspohl et al. 1995). The bisindolylmaleinimide-derivative Ro 31-8220 inhibits PKC $\alpha, \beta, \varepsilon$ and $\zeta$ (Wilkinson et al. 1993, Persaud \& Jones 1994) and $\boldsymbol{l}$ (Persaud \& Jones 1994) (only those isoenzymes are mentioned which are present in islets). Nonspecific effects of TPA cannot be excluded since no reliable control compound exists. The inactive phorbol esters do not possess all the nonspecific effects of the active phorbol esters (Kachintorn et al. 1992). The PKC isoenzyme selectivity of the different PKC inhibitors is important when regarding interpretation of the data. Isoenzymes are not thought to have redundant but specific effects. One way to interpret the data is to introduce specific antibodies to either isoenzyme into islets by the electroporation method (Verspohl \& Herrmann 1996, Verspohl et al. 1997) to knock out their effects; unfortunately, we did not get reproducible results by this method.

From our results it appears that the desensitization is affected by a specific isoenzyme which is present in rat pancreatic islets and is inhibited by TPA but not by staurosporin, Ro 31-8220 and PKC peptide(19-31). However, none of the enzymes found in islets (PKCa, $\mathrm{PKC} \beta, \mathrm{PKC} \delta, \mathrm{PKC} \varepsilon, \mathrm{PKC}$ and $\mathrm{PKCl}$ ) are inhibited by TPA, and none are simultaneously inhibited by any of the other inhibitors we have used. Thus a hitherto unknown PKC isoenzyme is involved in the desensitization process.
Another possible explanation for the different effects between TPA pretreatment and the different PKC inhibitors could be that protein kinase $\mathrm{M}$ is formed by the proteolytic degradation of PKC due to phorbol esters. In contrast the competitive inhibitors staurosporin, Ro 318220 and PKC peptide(19-31) do not produce this kinase. It might be speculated that this kinase is involved in the desensitization mediated by TPA.

A third explanation for the divergent effect of TPA could be that TPA exhibits additional nonspecific effects since TPA is known to induce a depolarization of plasma membranes (Yada et al. 1989), stimulation of phospholipase D (PLD) (Guillemain \& Rossignol 1994) and PLA 2 (Conklin et al. 1988) and an inhibition of epidermal growth factor (EGF) receptor tyrosine kinase (Lin et al. 1986). It is well known in the latter case that tyrosine kinase inhibition increases insulin release (Jonas et al. 1995, Verspohl et al. 1995).

In conclusion, the data indicates the involvement of $\mathrm{PKC}$, although a hitherto unidentified specific isoenzyme of PKC may be involved in the homologous desensitization of the CCh-induced insulin release in pancreatic islets.

\section{$\beta A R K$ ( $\beta$-adrenergic receptor kinase)}

Members of the GRK family are receptor-specific kinases. They phosphorylate the receptor in an agonist-dependent way and are involved in the homologous desensitization of 

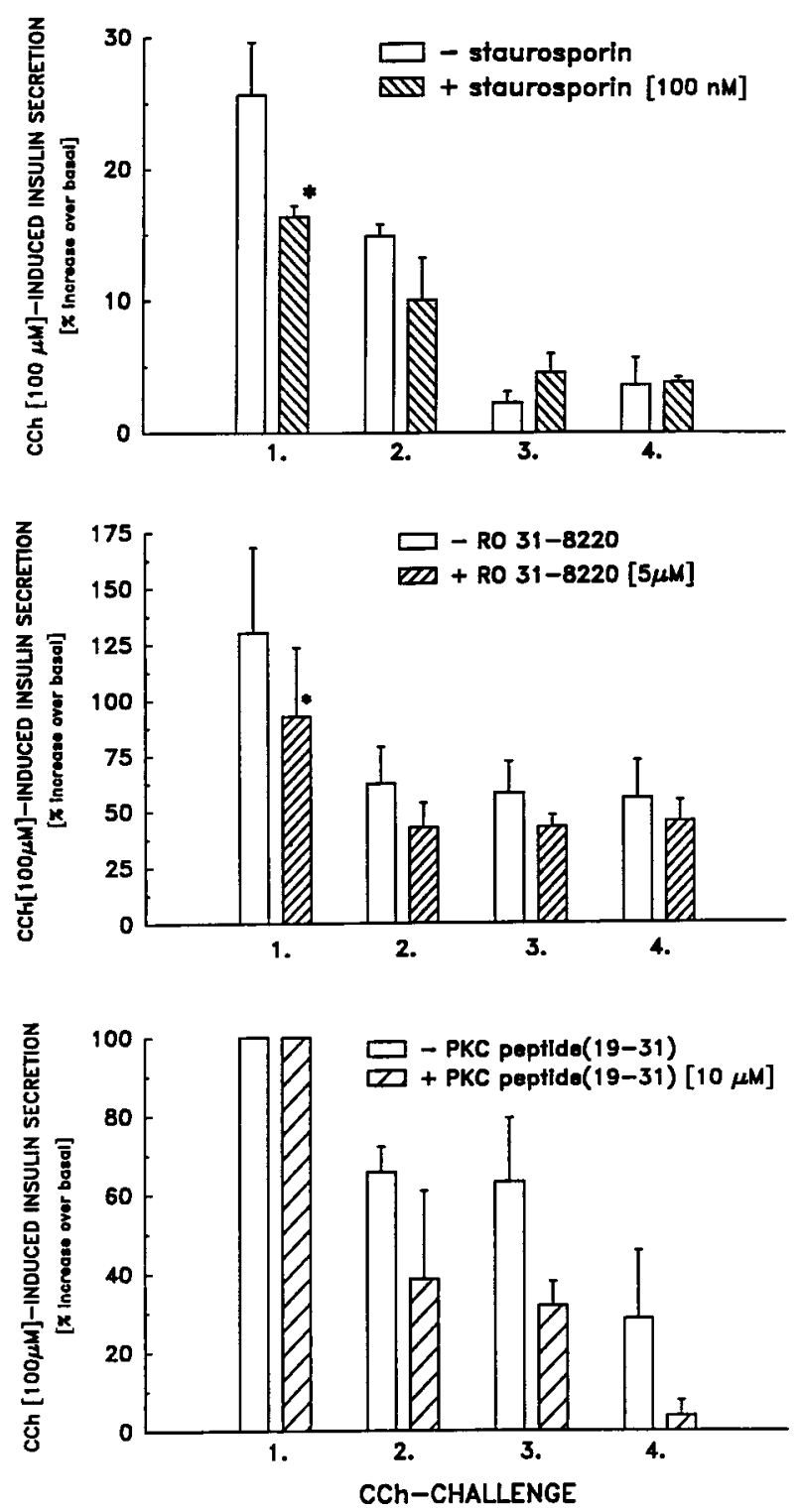

Figure 4 Effects of staurosporin, Ro 31-8220 and PKC peptide(19-31) on CCh effects on insulin release, with respect to desensitization. In the absence or presence of different PKC inhibitors (staurosporin upper panel; Ro 31-8220 middle panel; PKC peptide(19-31) lower panel), 50 rat pancreatic islets were perifused at a glucose concentration of $8.3 \mathrm{mM}$. The percentage increase of insulin secretion over basal (last 3 min prior to challenge) is shown for four CCh challenges. Data are expressed as means \pm S.E.M. of four experiments; one-way ANOVA $P<0 \cdot 002$ for desensitization in the absence of staurosporin; multi-way ANOVA $P<0.05$ for desensitization in the absence of Ro 31-8220; one-way ANOVA $P<0.05$ for desensitization in the absence of PKC peptide(19-31); ${ }^{*} P<0.05$ denotes the difference in the presence and absence of either staurosporin or Ro 31-8220 during the first challenge. Note that the data of the first CCh challenge with respect to PKC peptide(19-31) are normalized to $100 \%$ since the electroporation procedure resulted in day-to-day slightly variable basic secretion. some G-protein coupled receptors. Recent studies show that the $\mathrm{M}_{3}$ receptor is a substrate of GRK2 (Debburman et al. 1995), and GRK2 was shown to be present in the pancreas (Benovic \& Gomez 1993). It is known that the $\beta A R K$ inhibitor heparin prevents the augmenting effect of TPA on $\beta A R K$ desensitization and that $\beta A R K$ activity can be increased through phosphorylation by PKC (Chuang et al. 1995).

An involvement of GRK, however, does not seem to play a role with respect to $M_{3}$ receptor desensitization in islets since the GRK inhibitor heparin was not effective in our system, even though a high extracellular concentration $(50 \mu \mathrm{g} / \mathrm{ml})$ during electroporation was used. Heparin is also known to inhibit the $\mathrm{IP}_{3}$ receptor which is important for insulin release. The $\mathrm{IP}_{3}$ receptor being a calcium channel is involved in the desensitization in the way that an activation of PLC by $\mathrm{CCh}$ and the resulting increase in $\mathrm{IP}_{3}$ results in a proteolysis of the receptor (Simpson et al. 1994, Wojcikiewicz et al. 1993, 1994). However, since the heparin concentration used is able to inhibit $\mathrm{IP}_{3}$ receptors and since there was no effect of heparin pretreatment, this mechanism is unlikely to be involved in the CCh desensitization observed.

In conclusion there is clear evidence that in rat pancreatic islets $\mathrm{CCh}$ effects on insulin release desensitize quickly. Whereas PKC isoenzyme downregulation or inhibition is involved in diminished acute insulin response to $\mathrm{CCh}$, it is questionable which $\mathrm{PKC}$ isoenzyme is involved in the homologous $\mathrm{CCh}$ desensitization; three out of four different PKC inhibitors are unable to inhibit desensitization. This may be due to an unknown isoenzyme downregulated by TPA and not the other compounds used or by a nonspecific effect of TPA. The data are in contrast to a PKC involvement in homologous $\mathrm{M}_{3}$-subtype receptor desensitization, e.g. in pancreatic acini and lacrimal gland cells. Other possible mechanisms of desensitization have to be investigated, e.g. at the level of $G$ proteins.

\section{Acknowledgements}

We are thankful to Behringwerke AG, Germany, for supplying the labeled insulin.

\section{References}

Arkhammar P, Juntti-Berggren L, Larsson O, Welsh M, Nanberg E, Sjöholm A, Köhler M \& Berggren P-O 1994 Protein kinase C modulates the insulin secretory process by maintaining a proper function of the $\beta$-cell voltage-activated $\mathrm{Ca}^{2+}$ channels. Journal of Biological Chemistry 269 2743-2749.

Barr AJ \& Watson SP 1994 Protein kinase C mediates delayed inhibitory feedback regulation of human neurokinin type 1 receptor activation of phospholipase C in UC11 astrocytoma cells. Molecular Pharmacology 46 266-273. 
Benovic JL \& Gomez J 1993 Molecular cloning and expression of GRK 6. A new member of the $G$ protein-coupled receptor kinase family. Journal of Biological Chemistry 268 19521-19527.

Benya RV, Kusui T, Battey JF \& Jensen RT 1995 Chronic desensitization and down-regulation of the gastrin-releasing peptide receptor are mediated by a protein kinase C-dependent mechanism. Journal of Biological Chemistry 270 3346-3352.

Berrie CP \& Elliott AC 1994 Activation of protein kinase C does not cause desensitization in rat and rabbit mandibular acinar cells. European Journal of Physiology 428 163-172.

Birchall AM, Bishop J, Bradshaw D, Cline A, Coffey J, Elliot LH, Gibson VM, Greenham A, Hallam TJ, Harris W, Hill CH, Hutchings A, Lamont AG, Lawton G, Lewis EJ, Maw A, Nixon JS, Pole D, Wadsworth J \& Wilkinson SE 1994 RO 32-0432, a selective and orally active inhibitor of protein kinase C prevents T-cell activation. Journal of Pharmacology and Experimental Therapeutics 268 922-929.

Bruns RF, Miller FD, Merriman RL, Howbert JJ, Heath WF, Kobayashi E, Takahashi I, Tamaoki T \& Nakano H 1991 Inhibition of protein kinase $\mathrm{C}$ by calphostin $\mathrm{C}$ is light-dependent. Biochemical and Biophysical Research Communications 176 288-293.

Chuang TT, LeVine III H \& DeBlasi A 1995 Phosphorylation and activation of $\beta$-adrenergic receptor kinase by protein kinase $\mathrm{C}$. Journal of Biological Chemistry 270 18660-18665.

Conklin BR, Brann MR, Buckley NJ, Ma AL, Bonner TI \& Axelrod J 1988 Stimulation of arachidonic acid release and inhibition of mitogenesis by cloned genes for muscarinic receptor subtypes stably expressed in A9 L cells. Proceedings of the National Academy of Sciences of the USA 85 8698-8702.

Debburman SK, Kunapuli P, Benovic JL \& Hosey MM 1995 Agonist-dependent phosphorylation of human muscarinic receptors in Spodoptera frugiperda insect cell membranes by G protein-coupled receptor kinases. Molecular Pharmacology 47 224-233.

Dickenson JM \& Hill SJ 1993 Homologous and heterologous desensitization of histamine $\mathrm{H}_{1}$-receptors and ATP-receptors in the smooth muscle cell line, DDT(1)MF-2. The role of protein kinase C. British Journal of Pharmacology 110 1449-1456.

Doi R, Chowdhurya P \& Rayford P 1993 Agonist-regulated alteration of the affinity of pancreatic muscarinic cholinergic receptors. Journal of Biological Chemistry 268 22436-22443.

Fabiato A \& Fabiato F 1979 Calculator programs for computing the composition of the solutions containing multiple metals and ligands used for experiments in skinned muscle cells. Journal of Physiology $75463-505$

Frankel A \& Viallet J 1993 Protein kinase C is not involved in the homologous desensitization of bombesin responses in small cell lung cancer cells. Experimental Cell Research 209 398-401.

Gao ZY, Gilon P \& Henquin JC 1994 The role of protein kinase C in signal transduction through vasopressin and acetylcholine receptors in pancreatic B-cells from normal mouse. Endocrinology 135 191-199.

Guillemain I \& Rossignol B 1994 Receptor- and phorbol ester-mediated phospholipase D activation in rat parotid involves two different pathways. American Journal of Physiology 266 C692-C699.

Guma A, Munoz P, Camps M, Testar X, Palacin M \& Zorzano A 1992 Inhibitors such as staurosporin, H-7 or polymyxin B cannot be used in skeletal muscle to prove the role of protein kinase $\mathrm{C}$ on insulin action. Bioscience Reports 12 413-424.

Haga K, Haga T \& Ichiyama A 1990 Phosphorylation by protein kinase $\mathrm{C}$ of the muscarinic acetylcholine receptor. Journal of Neurochemistry 54 1639-1644.

Hishinuma S, Matsumoto Y, Uchida MK \& Kurokawa M 1993 Novel regulation of muscarinic receptors and their coupling with $G$ proteins in smooth muscle: transient resensitization during the desensitizing process. British Journal of Pharmacology 109 330-335.
Jonas JC, Plant TD, Gilon P, Detimary P, Nenquin M \& Henquin JC 1995 Multiple effects and stimulation of insulin secretion by the tyrosine kinase inhibitor genistein in normal mouse islets. British Journal of Pharmacology 114 872-880.

Jones PM, Persaud SJ \& Howell SL $1992 \mathrm{Ca}^{2+}$-induced insulin secretion from electrically permeabilized islets. Loss of $\mathrm{Ca}^{2+}$-induced secretory response is accompanied by loss of $\mathrm{Ca}^{2+}$-induced protein phosphorylation. Biochemical Journal 285 973-978.

Kachintorn U, Vongkovit P, Vajanaphanich M, Dinh S, Barrett KE \& Dharmsathaphorn K 1992 Dual effects of a phorbol ester on calcium-dependent chloride secretion by T84 epithelial cells. American Journal of Physiology 262 C15-C22.

Karlsson S \& Ahrén B 1991 Cholecystokinin-stimulated insulin secretion and protein kinase $\mathrm{C}$ in rat pancreatic islets. Acta Physiologica Scandinavica 142 397-403.

Kase H, Iwahashi K, Nakanishi S, Matsuda Y, Yamada K, Takahashi M, Murakata C, Sato A \& Kaneko M 1987 K-252 compounds, novel and potent inhibitors of protein kinase $\mathrm{C}$ and cyclic nucleotidedependent protein kinases. Biochemical and Biophysical Research Communications 142 436-440.

Kuo WN, Hods D \& Kuo FN 1973 Adenylate cyclase in islets of Langerhans. Journal of Biological Chemistry 248 2705-2711.

Lattion AL, Diviani D \& Cotecchia S 1994 Truncation of the receptor carboxyl terminus impairs agonist-dependent phosphorylation and desensitization of the $\alpha_{1 \mathrm{~B}}$-adrenergic receptor. Journal of Biological Chemistry $26922887-22893$.

Lee MH \& Bell RM 1986 The lipid binding regulatory domain of protein kinase C: a 32-kDa fragment contains the calcium- and phosphatidyl serine-dependent phorbol diester binding activity. Journal of Biological Chemistry 261 14867-14870.

Lin CR, Chen WS, Lazar CS, Carpenter CD, Gill GN, Evans RM \& Rosenfeld MG 1986 Protein kinase C phosphorylation at Thr 654 of the unoccupied EGF receptor and EGF binding regulate functional receptor loss by independent mechanisms. Cell $\mathbf{4 4}$ 839-848.

Lin W-W \& Chuang D-M 1993 Agonist-induced desensitization of ATP receptor-mediated phosphoinositide turnover in C6 glioma cells: comparison with the negative-feedback regulation by protein kinase C. Neurochemistry International 23 53-60.

McArdle CA, Willars GB, Fowkes RC, Nahorski SR, Davidson JS \& Forrest-Owen W 1996 Desensitization of gonadotropin-releasing hormone action in $\alpha \mathrm{T} 3-1$ cells due to uncoupling of inositol 1,4,5-triphosphate generation and $\mathrm{Ca}^{2+}$ mobilization. Journal of Biological Chemistry 271 23711-23717.

McGlynn E, Liebetanz J, Reutener S, Wood J, Lydon NB, Hofstetter H, Vanek M, Meyer T \& Fabbro D 1992 Expression and partial characterization of rat protein kinase $\mathrm{C}-\mathrm{d}$ and protein kinase $\mathrm{C}-\mathrm{z}$ in insect cells using recombinant baculovirus. Journal of Cellular Biochemistry 49 239-250.

Maruyama Y 1989 Activation and desensitization mechanisms of muscarinic current response in single pancreatic acinar cells of rats. Journal of Physiology 417 343-359.

Mizuno K, Saido TC, Ohno S, Tamaoki T \& Suzuki K 1993 Staurosporin-related compounds, K252a and UCN-01, inhibit both $\mathrm{cPKC}$ and nPKC. Proceedings of the Meeting of the Federation of European Biochemical Societies 330 114-116.

Nixon JS, Bishop J, Bradshaw D, Davis PD, Hill CH, Elliott LH, Kumar H, Lawton G, Lewis EJ, Mulqueen M, Westmacott D, Wadswoth J \& Wilkinson SE 1992 The design and biological properties of potent and selective inhibitors of protein kinase C. Biochemical Society Transactions 20 419-425.

Persaud SJ \& Jones PM 1994 Inhibition of insulin release by staurosporin and Ro 31-8220: a role for protein kinase C? Biochemical Society Transactions 22 208S.

Persaud SJ, Jones PM, Sugden D \& Howell SL 1989 Translocation of protein kinase $\mathrm{C}$ in rat islets of Langerhans. Effects of a phorbol ester, carbachol and glucose. FEBS Letters 245 80-84. 
Potter LR \& Garbers DL 1994 Protein kinase C-dependent desensitization of the atrial natriuretic peptide receptor is mediated by dephosphorylation. Journal of Biological Chemistry 269 14636-14642.

Simpson PB, Challiss RAJ \& Nahorski SR 1994 Chronic activation of muscarinic and metabotropic glutamate receptors down-regulates type I inositol 1,4,5-trisphosphate receptor expression in cerebellar granule cells. Journal of Neurochemistry 63 2369-2372.

Tamaoki T, Nomoto H, Takahashi I, Kato Y, Morimoto M \& Tomita F 1986 Staurosporin, a potent inhibitor of phospholipid/ $\mathrm{Ca}$-dependent protein kinase. Biochemical and Biophysical Research Communications 135 397-402.

Tan YP \& Marty A 1991 Protein kinase C-mediated desensitization of the muscarinic response in rat lacrimal gland cells. Journal of Physiology 433 357-371.

Tang H, Shirai H \& Inagami T 1995 Inhibition of protein kinase C prevents rapid desensitization of type $1 \mathrm{~B}$ angiotensin II receptor. Circulation Research 77 239-248.

Tobin AB, Keys B \& Nahorski SR 1993 Phosphorylation of a phosphoinositidase C-linked muscarinic receptor by a novel kinase distinct from $\beta$-adrenergic receptor kinase. Proceedings of the Meeting of the Federation of European Biochemical Societies 335 353-357.

Ueda H, Miyamae T, Hayashi C, Watanabe S, Fukushima N, Sasaki Y, Iwamura T \& Misu Y 1995 Protein kinase C involvement in homologous desensitization of delta-opioid receptor coupled to Gi1-phospholipase C activation in Xenopus oocytes. Journal of Neuroscience 15 7485-7499.

Verspohl EJ \& Ammon HPT 1980 Evidence for presence of insulin receptors in rat islets of Langerhans. Journal of Clinical Investigation 65 1230-1237.

Verspohl EJ \& Herrmann K 1996 Involvement of G proteins in the effect of carbachol and cholecystokinin in rat pancreatic islets. American Journal of Physiology 271 E65-E72.

Verspohl EJ, Tacke R, Mutschler E \& Lambrecht G 1990 Muscarinic receptor subtypes in rat pancreatic islets: binding and functional studies. European Journal of Pharmacology 178 303-311.

Verspohl EJ, Tollkühn B \& Kloss H 1995 Role of tyrosine kinase in insulin release in an insulin secreting cell line (INS-1). Cellular Signalling 7 505-512.

Verspohl EJ, Kaiserling-Buddemeier I \& Wienecke A 1997 Introducing specific antibodies into electropermeabilized cells is a valuable tool for knocking out specific cell functions, e.g. Gprotein function. Cell Biochemistry and Function 115 127-134.
Wilkinson SE, Parker PJ \& Nixon JS 1993 Isoenzyme specificity of bisindolylmaleimides, selective inhibitors of protein kinase C. Biochemical Journal 294 335-337.

Willems PHGM, Van Hoof HJM, Van Mackelenbergh MGH, Hoenderop JGJ, Van Emst-DeVries SE \& De Pont JJHHM 1993 Receptor-evoked $\mathrm{Ca}^{2+}$ mobilization in pancreatic acinar cells: evidence for a regulatory role of protein kinase $\mathrm{C}$ by a mechanism involving the transition of high-affinity receptors to a low-affinity state. Pflügers Archiv 424 171-182.

Wojcikiewicz RJH, Tobin AB \& Nahorski SR 1993 Desensitization of cell signalling mediated by phosphoinositidase C. Trends in Pharmacological Sciences 14 279-285.

Wojcikiewicz RJH, Furuichi T, Nakade S, Mikoshiba K \& Nahorski SR 1994 Muscarinic receptor activation down-regulates the type I inositol 1,4,5-trisphosphate receptor by accelerating its degradation. Journal of Biological Chemistry 269 7963-7969.

Wollheim CB \& Regazzi R 1990 Protein kinase C in insulin releasing cells. Putative role in stimulus secretion coupling. FEBS Letters 268 376-380.

Yada T, Russo LL \& Sharp GWG 1989 Phorbol ester-stimulated insulin secretion by RINm5F insulinoma cells is linked with membrane depolarization and an increase in cytosolic free $\mathrm{Ca}^{2+}$ concentration. Journal of Biological Chemistry 264 2455-2462.

Yamatani T, Chiba T, Kadowaki S, Hishikawa R, Yamaguchi A, Inui T, Fujita T \& Kawazu S 1988 Dual action of protein kinase C activation in the regulation of insulin release by muscarinic agonist from rat insulinoma cell line (RINr). Endocrinology 122 2826-2832.

Yaseen MA, Pedley KC \& Howell SL 1982 Regulation of insulin secretion from islets of Langerhans rendered permeable by electric discharge. Biochemical Journal 206 81-87.

Zamani MR, Dupere JRB \& Bristow DR 1995 Receptor-mediated desensitization of histamine $\mathrm{H}_{1}$-receptor-stimulated inositol phosphate production and calcium mobilisation in GT1-7 neuronal cells is independent of protein kinase C. Journal of Neurochemistry $\mathbf{6 5}$ 160-169.

Zawalich WS \& Kelley GG 1995 The pathogenesis of NIDDM: the role of the pancreatic beta cell. Diabetologia 38 986-991.

Received 4 March 1998

Revised manuscript received 11 June 1998 Accepted 30 June 1998 